\title{
Public finance in the Republic of Croatia: current state and outlook
}

ZDRAVKO MARIĆ, Ph.D.

Conference introductory note*

https://doi.org.10.3326/pse.41.1.5

\footnotetext{
* Received: February 7, 2017

Accepted: February 9, 2017
}

A conference introductory note was held at the conference Public Sector Economics organized by the Institute of Public Finance and Friedrich-Ebert-Stiftung in Zagreb on October 14-15, 2016. 
At the moment Croatia is facing a number of economic challenges as well as numerous opportunities. The challenges are for the most part related to the consequences of the economic crisis that began six years ago and the need to reduce budgetary and macroeconomic imbalances. The importance of this line of action in economic policy is further reflected in European Commission findings which point to the vulnerabilities of the Croatian economy and the consequential assessment of the possibility to introduce corrective measures that could ultimately result in the freezing of EU funds. Moreover, fiscal vulnerabilities have resulted in excessive deficit procedure being launched in January 2014, whereby Croatia was obliged, in accordance with Council recommendations, to reduce the deficit to $2.7 \%$ of GDP by the end of 2016 and ensure sustainable trajectory of public debt.

On the other hand, a number of indicators point to favourable economic trends, notably high-frequency macroeconomic indicators including industrial production, the number of tourists' overnight stays, real turnover in retail trade and construction works show an upward trend, while exports and employment rates are increasing. The forecasted GDP growth rate for 2016 will thus significantly exceed initial expectations. Over the medium term the positive trends are expected to continue, with a gradual increase in economic activity. In 2017 and 2018 GDP is projected to increase by $3.2 \%$, this increase rising to $3.3 \%$ in 2019 . It should be noted that projected general government deficit in 2016 will be significantly lower than initially forecasted. Moreover, the debt-to-GDP ratio is declining for the first time since 2007 and is projected to reach $83.9 \%$ at the end of 2016 , which is almost 3 pp below the ratio registered at the end of 2015 .

\section{ADDRESSING STRUCTURAL VULNERABILITIES}

The Government thus has the responsibility to strongly address the structural vulnerabilities and give additional impetus to favourable economic trends, thus steering the Croatian economy towards sustained and stable growth that will lead to a higher standard of living for Croatian citizens. In order to achieve these goals, comprehensive and decisive reform measures are called for, both on the revenue and expenditure sides of the budget.

In that regard, a comprehensive tax reform, which came into effect at the beginning of 2017, will play a key role. The reform package encompasses 15 acts, seven of which are new, aiming at a simpler, more stable and fairer tax system while reducing the total tax burden and making it more competitive. Shifting the tax burden away from entrepreneurs and citizens and having a simpler and more stable tax framework will facilitate economic growth as well as employment rate growth, improve the competitiveness of the economy, social fairness and demographic renewal, prevent highly educated individuals from leaving the country, and foster entrepreneurship, trades, and agriculture. Available fiscal options were taken into consideration in the course of the reform drafting process, as were the sustainability of public finance and the sustainability of financing local and regional self-government units. 
The total reduction of the tax burden during its first year of application is projected to amount to $0.7 \%$ of GDP and will be based primarily on a reduction of the direct taxation of income and profits, resulting in an increase in personal spending and investment. It should be noted that, according to recent OECD and ECB studies, a 1 percentage point reduction of the tax-to-GDP ratio translates into a longterm growth rate increase of between $0.25 \%$ and $1 \%$, and the reduction of direct taxation has a more significant positive impact on long-term growth than the reduction of indirect taxation. We expect those measures to result in a 0.3-0.5 pp difference in the mid-term rate of potential GDP growth.

However, the tax reform is but one segment of the comprehensive consolidation of public finance by way of structural reforms which must first of all aim at efficient public funds management when it comes to health care and the pension and social system. Moreover, the justice and administrative system reforms are of special importance since legal certainty, together with a stable tax system, is essential to achieving overall economic stability, which is in turn one of the key requirements for economic growth.

\section{FISCAL SUSTAINABILITY AND ENHANCING ECONOMIC GROWTH}

Key efforts in the upcoming period will be focused on the continuation of fiscal sustainability while stimulating economic growth. Special attention should be paid to areas showing significant growth potential, especially agriculture, where emphasis should be put on alimentary independence and security and the modernization of rural facilities. Another important sector is tourism, where additional investments need to be made into accommodation capacities as well as into domestic tourist spending by introducing the Cro Card tourist voucher. Steps are also being taken to reduce administrative and regulatory burden, aiming at enhancing the effects of the tax reform in order to boost entrepreneurial activities. Making a better use of EU funds will give an additional boost to and increase the funds available for development and infrastructure projects, as well as for research and innovation. EU funds are, moreover, a key instrument for the strengthening of development capacities in different parts of Croatia.

Apart from the economy, another key challenge, as well as a key potential of a country, are its people. Negative demographic trends along with increased emigration and global migration in general are a clear warning that swift action is called for while having in mind development over the medium term and over the long term. Focus should be put on of demographic sustainability. For this reason child allowances and allowances for dependents have already gone up this year and there are plans to introduce a subsidy scheme on loans for first-time home buyers under 45 . Allowances for additional maternity leave are to be increased as well. It should also be noted that social justice and inclusion will be taken into account in the process of shaping and managing economic policies so as to ensure protection and solidarity to vulnerable groups. 
Apart from the above mentioned development efforts, focus must be placed on fiscal sustainability since long-term public finance stability is the foundation of overall economic stability and a precondition for sustainable growth. In that sense, expenditure growth, shaped by development requirements and social responsiveness, will be strongly focused on the continuation of fiscal consolidation, among other things increasing budgetary planning efficiency and the fiscal responsibility of budgetary beneficiaries.

\section{DECREASING DEFICITS AND DEBTS}

The above fiscal efforts, on both the revenue and the expenditure side of the budget, will result in general government deficit amounting to $1.6 \%$ of GDP in $2017,1 \%$ in 2018 and $0.6 \%$ of GDP in 2019 according to ESA 2010, thus meeting the criteria for the abrogation of the excessive deficit procedure in the upcoming period and helping reduce the debt-to-GDP ratio.

Indeed, high public debt, reaching 289.6 billion HRK or $86.7 \%$ of GDP at the end of 2015, places a great burden on overall economic policy while the related risks increase public finance vulnerability. Cyclical disturbances and structural rigidities demonstrated the scale and expansion rate of government debt in the period between 2008 and 2015, which increased by 152 billion HRK or from 39.6\% of GDP to the aforementioned $86.7 \%$ of GDP in that period.

Economic recovery after several years of economic downturn spurred fiscal consolidation efforts and effects, resulting in curbing the years-long excessive annual debt-to-GDP rate growth. The existing macroeconomic projections suggest a reduction of refinancing risk over the short term and a reversal of this negative trend. However, due to the high level of government debt, a comprehensive and proactive approach will have to be adopted in order to strengthen long-term debt sustainability and mitigate the effect of debt-related risks. To that end, the Government has developed the 2017-2019 Government Debt Management Strategy which defines the manner of meeting budget financing needs and designs the debt structure by selecting markets, instruments, and debt issuance date.

The basic goal of borrowing and debt management is to ensure that the government's financing needs and its payment obligations are met at the lowest possible cost over the medium and long term, while at the same time taking prudent approach to risk constraints. Therefore, the Government's main strategic goal and a national priority is to reduce the debt-to-GDP ratio by more than 10 percentage points by the end of 2020, which requires coordinated and consistent economic policy measures based on three key pillars: fostering economic growth, continuing fiscal consolidation and the privatization of state-owned assets. These efforts will result in a further reduction of the debt-to-GDP ratio from $81.5 \%$ in 2017 to $78.6 \%$ in 2018 and $75.3 \%$ in 2019 . In the medium term, short-term debt ratio should fall from the current $13.2 \%$ to $11.9 \%$ in 2019 . Moreover, debt maturity is expected to be slightly extended. Even though approximately three quarters of the 
debt are denominated in foreign currencies - mostly in EUR - either directly or by way of currency clauses, the related currency risk is partially mitigated by favourable conditions on the domestic capital market. A further mild increase of the debt component denominated in HRK is projected. As to currency risk, approximately $87 \%$ of the debt carries a fixed interest rate while the remaining $13 \%$ carries a variable interest rate; in the refinancing of the debt over the short term the price of new borrowing and the refinancing of existing debt at a lower nominal interest rate will be of primary concern. Over the medium term this risk will be reduced by means of consistently sustainable fiscal policy and, consequentially, improving the credit rating and thus reducing the current higher risk premium.

The aforementioned measures will result in improving government debt sustainability and reducing debt-related risk. Such measures, along with the abrogation of the excessive deficit procedure within the shortest time frame possible, will enable the continuation of sustainable, reasonable and balanced fiscal policy, thus ensuring the realisation of the key priorities of the Government's economic policy: the permanent reduction of the debt burden and the improvement of the credit rating. 